from some of the best teaching centres in the U.S.the Massachusetts Institute of Technology, Princeton, Swarthmore, Dartmouth and Bryn Mawr are examples only.

An error in the design of the mass spectrometer was noted: the slideways employ two vee-grooves, and impose too many constraints; one vee-groove and one flat should be used. Oddly, too, the drawings are full of redundant dimensions leaving the amateur mechanic too many checks to do and the professional a problem in deciding which to use as his reference planes. The shop equipment needed for each construction is listed (lathe, mill, air-gas torch, hand solder, etc.), and so are tho materials and Amorican sources of supply of some of them. One difficulty to be anticipated is that British standard fittings (screws, pipes, couplings) seldom match the American counterparts. It seems likely, however, that constructional kits for some of the apparatus are now available.

The letterpress occupics about the same number of pages as the drawings. In it, there are hints, warnings and advice about use, evidently prepared for the college lecturer (the art of making vaeuum-tight soldered joints; field homogeneity and many tricks in the nuclear magnetic resonance apparatus).

The average educational level of the work seems to be about that of the college of advanced technology in Britain. Probably such colleges will benefit most of all from it, but other technical colleges and traditional universities will find it helpful too. Simply to open it is like a child's first visit to a Christmas toyshop; the brain seethes with phantom adventures and ideas.

After sober consideration, many of our teaching institutions are certain to benefit from this original but sensible work.

A. R. Meetham

\section{BOOKS ON NUCLEAR GRAPHITE}

\section{Nuclear Graphite}

OEEC Dragon Project Symposium, Bournemouth, November, 1959. Pp. 269. (Paris: Organization for European Economic Co-operation; European Nuclear Energy Agency, 1961.) n.p.

7 HE Organization for European Co-operation and Development (OECD) Dragon high-temperature gascooled, nuclear reactor project has now been in operation since 1959, and indeed the $25 \mathrm{MW}$ experimental reactor is due to start up at the Atomic Energy Establishment, Winfrith, during next year. The project held its first symposium at Bournemouth in November 1959, and it was very appropriate that this first technical meeting should havo been devoted entirely to graphite because, as the chief executive, C. A. Rennie, pointed out in his opening remarks, the whole concept of the Dragon reactor is based on the use of this material. Although the European Nuclear Energy Agency did not publish the proceedings of this conference until July 1961, the mass of information given on graphite manufacturing technology was, and still is, worthy of the attention of a much wider audience than the small one which met at Bournemouth in 1959. The publication in the United States of a more recent work with the same title, Nuclear Graphite (Nature, $128,420,1962)$ prompts a further glance at the earlier book from the European Organization.

The introductory paper by Dr. L. R. Shepherd outlined the design philosophy behind the Dragon reactor system, concluding that fuel element components would have to be developed to stand temperatures of $1,000-1,700^{\circ} \mathrm{C}$, in an intense neutron field. Since graphite had been selected as tho moderator, the main structural member and the fission product containment barrier in the core, the real purpose of the symposium was to assess what processes were currently available or capable of development for producing a suitable form of graphite.
It appeared that a fine-grained graphite of very low permeability and nuclear purity was required, and at the session on manufacture and properties of fine-grain graphite, papers from Morgan Crucible Co., Atomic Energy Research Establishment Chemical Engineering Division, Siemens-Planiawerke (Germany), Société Le Carbone Lorraine (France) and Société Pechiney (France) were presented to show the possibilities in this direction.

Impregnation techniques, as a means of lowering the permeability of fine-grained graphite, were also described, and finally, the various methods used in the laboratory for assessing the more important properties of the final graphite were described.

The title Nuclear Graphite for this collection of papers is somewhat misleading, since the book does not give any experience of the behaviour of graphite in-pile, and is solely devoted to considering the special form of graphite required for the Dragon high temperature gas-cooled reactor. Nevertheless, the information published on graphite-making is a valuable contribution to the literature, since so fow papers appearing, prior to, or since this date have disclosed rocipes for making special graphitic materials on a commercial scale.

F. Roberts

\section{DESCRIPTIVE OCEANOGRAPHY}

The Sea: Ideas and Observations on Progress in the Study of the Seas

Vol. 2 : The Composition of Sea-Water, Comparative and Descriptive Oceanography. General Editor M. N. Hill. Pp. $\mathrm{xv}+554$. (New York and London: Interscience Publishers, a division of John Wiley and Sons, 1963.) $150 s$.

7 HIS is the second of a series of three volumes surveying the present position in physical, chemical and geological oceanography. For reasons of space, marine biology has only been included where it has a direct boaring on these three fields of study.

Following the first volume on physical oceanography, Volume 2 contains a series of review articles on the chemistry and fertility of sea-water, the biological problems related to the various water masses-productivity, fishery dynamics and the distribution of organisms-and largely descriptive accounts of some of the principal current systems. Also included are some fascinating miscellanea such as the largely unexplained seasonal changes in sea-level, a topical discussion of bathyscaphs and deep submersibles, and the navigational and observational uses of the gyropendulum.

Some subjects which appoar in this volume, chemical sampling instruments for example, are as old as oceanography itself, whilo others such as estuary dynamics or the use of neutral buoyant floats are of such recent development as to appear in a collected volume for the first time. It is most noticeable how in recent years a gradual dissolution of the traditional subject barriers has occurred. Chemistry and biology are now largely inseparable in oceanography, and both contribute to our knowlodge of physical and dynamical processes. The geographical distribution of both organic and inorganic matter is closely relatod to the current systems, and a knowledge of these distributions provides information. which would othorwise require extensive serios of current measurements. The very oxtent of the oceans makes the task of gathering information most formidable, and in this context the present international programme of observations in the Indian Ocean will prove of great value. It is gratifying to read that oven radioactive fall-out yields somo useful information on oceanic mixing and the general circulation.

The exports contributing to this volume continue the extremely high standard set in Volume 1 , both in comprehensiveness and in the stimulating presentation of their specia] topics. Not only oceanographers but also all 